\title{
LA JUSTICIA MILITAR FRANQUISTA CONTRA EL DIRECTOR DE CINE FLORIÁN REY Y EL ACTOR MIGUEL LIGERO.
}

\author{
The francoist court against \\ the film director Florián Rey and the actor Miguel Ligero
}

Carlos Illana y Juan Miguel Campanario

Universidad de Alcalá

carlos.illana@uah.es

juan.campanario@uah.es

Recibido: 20/06/2017 - Aceptado: 22/11/2017

Cómo citar este artículo/Citation:

Carlos ILLANA y Juan Miguel CAMPANARIO (2018), "La justicia militar franquista contra el director de cine Florián Rey y el actor Miguel Ligero.", Hispania Nova, 16, págs. 293-328, DOI: https://doi.org/10.20318/hn.2018.4039
Copyright: (c) HISPANIA NOVA es una revista debidamente registrada, con ISSN II38-7319 y Depósito Legal M 9472-1998. Los textos publicados en esta revista están -si no se indica lo contrario- bajo una licencia Reconocimiento-Sin obras derivadas 3.0 España de Creative Commons. Puede copiarlos, distribuirlos y comunicarlos públicamente siempre que cite su autor y la revista y la institución que los publica y no haga con ellos obras derivadas. La licencia completa se puede consultar en: http://creativecommons.org/licenses/by-nd/3.0/es/deed.es
Resumen: En este trabajo se analiza la detención por la Guardia Civil y la posterior investigación que sufrieron, por parte de la justicia militar franquista, el director de cine Florián Rey, el actor Miguel Ligero y otras personas relacionadas con ellos. Este episodio se produjo en 1945 durante el rodaje en Aranjuez de la película La Luna vale un millón (Florián Rey, 1945) y estuvo motivado por la denuncia de un antiguo actor, Luis Infiesta Rojas. Al parecer, los encausados habrían efectuado afirmaciones contra el ejército español y a favor del comunismo. Los implicados negaron las acusaciones y presentaron diversos testigos que avalaron su fidelidad al Régimen franquista. Después de varias semanas en prisión, los arrestados fueron liberados y el expediente judicial militar fue archivado. Parece evidente en este caso que ni siquiera una posición social elevada y una fidelidad fuera de toda duda al Régimen franquista podía evitar que la justicia militar pusiese en marcha su maquinaria ante posibles amenazas al mismo.

Palabras clave: Florián Rey, Miguel Ligero, Justicia militar, Franquismo, Historia del cine.

\begin{abstract}
This work analyzes the arrest by the Civil Guard and the subsequent investigation by the francoist military court, of the film director Florián Rey, the actor Miguel Ligero and others related to them. This episode occurred in 1945 during the filming in Aranjuez of the movie La Luna vale un millón (Florián Rey, 1945) and was motivated by the complaint of a former actor, Luis Infiesta Rojas. Apparently, the accused would have made affirmations against the Spanish army and in favor of communism. Those implicated denied the accusations and presented several witnesses who endorsed their fidelity to the Franco regime. After several weeks in prison, the arrested were released and the military court process was filed. It seems evident in this case that not even a high social position and a fidelity beyond doubt to the francoist Regime could prevent the military justice to start up a process originated by possible threats to it.
\end{abstract}

Keywords: Florián Rey, Miguel Ligero, Military court, Francoism, Film history. 


\section{Introducción: Cineastas detenidos por hablar supuestamente mal del Ejército Español}

A finales de abril de 1945, cuando la Segunda Guerra Mundial daba sus últimos coletazos en Europa, el director Florián Rey se encontraba rodando en Aranjuez algunos exteriores de su película La Luna vale un millón (Florián Rey, 1945) ${ }^{1}$. Esta cinta estaba protagonizada por Miguel Ligero, Leonor Fábregas y Alicia Palacios ${ }^{2}$. Se trata de una comedia que cuenta la historia de un millonario que tiene un accidente de avioneta. Mientras se encuentra inconsciente, un vagabundo que vive cerca y que tiene un gran parecido físico con él cambia su ropa y decide suplantarle. A partir de ahí, el vagabundo convertido en millonario organizará toda clase de líos, mientras que el millonario tendrá que vivir como un vagabundo ${ }^{3}$.

Lo que no esperaba, sin duda, ningún miembro del equipo de rodaje de la película era verse envuelto en un lío todavía mayor, pero esta vez con la justicia militar franquista y todo por unas frases dichas tal vez algo a la ligera. En efecto, el día 28 de abril (sábado) se reunieron para cenar en el hotel Pastor ${ }^{4}$ Florián Rey (cuyo verdadero nombre era Antonio Martínez del Castillo) y Miguel Ligero Rodríguez, director y protagonista de la película. Estaban acompañados por dos parejas de conocidos del

\footnotetext{
${ }^{1}$ En el libro José Luis Lindo Martínez, sobre los estudios cinematográficos de Aranjuez, en el que se recogen todas las películas rodadas en Aranjuez, no se cita a esta película. El libro está escrito por el cronista oficial de aquella localidad y probablemente no fuera consciente de que La luna vale un millón (Florián Rey, 1945) se rodó, en parte, en Aranjuez. Es posible que no conozca el incidente que se relata en este artículo. José Luis LINDO MARTINEZ, Los estudios cinematográficos de Aranjuez, La Meca del Cine Español. 1932-1948, Salamanca, Gestión 10, 2007.

${ }^{2}$ Base de datos de película españolas. Ministerio de Educación Cultura y Deportes. Consultado el 1 de marzo de 2017.

${ }^{3}$ Archivo General de la Administración, expediente de censura de la película La Luna vale un millón, caja 36/0324.

${ }^{4}$ El hotel Pastor era un antiguo edificio del siglo XVIII (antiguo palacio de Godoy), que estaba situado en la Avenida del Príncipe. En el primer tercio del siglo XX fue un referente de Aranjuez por el glamour de sus huéspedes José Luis LINDO MARTINEZ, "El hotel Pastor". Fiestas de San Fernando, Aranjuez, recuperado de https://joseluislindo.wordpress.com/2014/05/24/el-gran-hotel-pastor-articulo-en-el-librode-fiestas-san-fernando-2014-del-cronista-oficial-de-aranjuezl, consultado el 24 de febrero de 2017. Actualmente en el edificio está instalado el colegio concertado Sagrada Familia.
} 
primero: Evaristo González Aguilar, Monique Beltrán Broussoux, Rogelio Periquet Rufilanchas y María Teresa Giralt Gómez y algún otro comensal que se incorporó más tarde. Durante la conversación, que se inició en la sobremesa se les unió Luis Infiesta Rojas, empresario local que explotaba el cine Gran Teatro. En este cine se proyectaban los fragmentos de película que se iban rodando en la localidad. Ninguno de los comensales sabía, al parecer, que Luis Infiesta Rojas iba a denunciarlos por realizar "manifestaciones derrotistas y en un sentido francamente desafecto al actual Régimen". El resultado de esta denuncia fue que los principales implicados pasaron varias semanas en prisión. Como consecuencia, el rodaje de la película se vio interrumpido con las consecuencias económicas negativas para la empresa que cabe esperar.

En el expediente número 130651 depositado en el Archivo General Histórico de Defensa se recoge todo el procedimiento que vamos a relatar ${ }^{5}$. Esta fuente, junto con otras del Archivo General de la Administración, el portal PARES y la prensa histórica de la época, permiten reconstruir las circunstancias de los hechos que narramos en este trabajo ${ }^{6}$.

La única referencia publicada que conocemos es la que hace el crítico cinematográfico Manuel Rotellar en un artículo periodístico titulado "Vigencia de Florián Rey". En este trabajo, Rotellar afirma lo siguiente: "Fue muy sonado su arresto en Aranjuez por un incidente del que poco se ha dicho o escrito En aquel arresto fue también víctima el cómico Miguel Ligero"7. Otro autor, Agustín Sánchez Vidal, en su libro "El cine de Florián Rey" recoge textualmente lo que indica Rotellar y cita a una testigo presencial cuyo nombre no hemos encontrado en la documentación que hemos estudiado. Además, afirma erróneamente que la detención duró sólo tres días y que el motivo fue un comentario desafortunado sobre la hija del general Franco ${ }^{8}$.

\footnotetext{
${ }^{5}$ Archivo General Histórico de Defensa, expediente número 130651, caja 797/6.

${ }^{6}$ Cuando no se indique otra cosa y con el fin de evitar incluir demasiadas notas a pie de página, se entiende que todas las afirmaciones literales están tomadas del expediente número 130651, caja 797/6.

${ }^{7}$ Manuel ROTELLAR, "Vigencia de Florián Rey", Andalán, 272 (1980) 6 al 12 de junio, 16.

${ }^{8}$ Agustín SÁNCHEZ VIDAL, El cine de Florián Rey, Caja de Ahorros de La Inmaculada, Zaragoza, 1991, pág. 339-341.
} 
Sin embargo, no tenemos conocimiento de que nadie hasta este momento haya narrado con detalle este episodio, sin duda desagradable, en la vida y carrera de personajes tan conocidos como el director Florián Rey y el actor Miguel Ligero. Gracia a la disponibilidad, desde el año 2009, en el Archivo General Histórico de Defensa de Madrid de los sumarios abiertos por la justicia militar franquista, hemos podido hacer un estudio en profundidad de este interesante episodio.

\section{La denuncia y las primeras declaraciones ante la Guardia Civil}

Según sus declaraciones posteriores, Luis Infiesta Rojas, el denunciante, acudió al hotel Pastor a tomar café y saludar a Florián Rey y otros artistas de cine y para "preguntarles a qué hora iban a proyectar los trozos de película que en la actualidad se encuentran rodando". En el transcurso de la conversación se habló de la contienda actual y entonces fue cuando, según Infiesta, Miguel Ligero dijo "que nuestro ejército era una birria". Según el denunciante, la cosa no quedó ahí, sino que el conocido actor continuó ensalzando al ejército norteamericano en el sentido de considerarlo dotado de un gran patriotismo, ya que cuando "han visto la patria en peligro han acudido todos como un solo hombre, incluso el artista cinematográfico Clark Gable, mientras que (en) el nuestro, los militares de carrera, que para eso cobran, son los primeros en 'enchufarse' y en cambio envían al frente a cuatro desgraciados". Al parecer, Florián Rey intervino varias veces en la conversación "dando su asentimiento a estas manifestaciones derrotistas" lo que demostraría que también era desafecto a la Causa Nacional.

Por si fuera poco, según Infiesta, la conversación se desvió y uno de los presentes, Rogelio Periquet Rufilanchas, defendió el comunismo, mientras su mujer, Teresa Giralt Gómez, se habría despachado a gusto diciendo que "Rusia había dado ocho millones de hombres en la actual contienda y que, por lo tanto, tenía derecho a formular exigencias, una de las cuales probablemente sería pedir cuentas a España por haber enviado la División Azul a combatir contra ella y que ya veríamos a ver cómo respondían las madres españolas por haber consentido que sus hijos fueran a luchar contra Rusia". 
Movido por la denuncia presentada por Luis Infiesta, el capitán de la Guardia Civil de Aranjuez, Luis Castro Samaniego, se puso rápidamente en movimiento. La primera diligencia se efectuó a partir de la llamada de teléfono del citado capitán de la Guardia Civil al jefe superior de Policía de Madrid. Este dispuso que saliesen desde Madrid a Aranjuez nada menos que un inspector y dos agentes de la Brigada PolíticoSocial. A su llegada, el día 30 de abril, tiene lugar un encuentro entre los funcionarios de Madrid y el capitán de la Guardia Civil de la localidad, y acuerdan todos que el inspector cite por separado al denunciante (Luis Infiesta), del que, según el capitán se "tiene conocimiento de que se trata de persona afecta a la causa Nacional", así como a cada uno de los denunciados para prestar declaración.

En un escrito posterior, el capitán de la Guardia Civil explicó que cuando se enteró de las declaraciones anteriores, dado que solamente había un testigo del delito, organizó un nuevo servicio para sorprender nuevas conversaciones. En este punto fue cuando solicitó a la Dirección General de Seguridad agentes que empezaron la práctica del servicio que nada dio por resultado, ya que los cineastas se abstuvieron de volver a hablar en la forma que lo hicieron en presencia del "confidente D. Luis Infiesta Rojas".

Posteriormente, Luis Infiesta Rojas se ratificará en todas las declaraciones anteriores e incluso añadirá algo más: el actor Miguel Ligero había desertado del ejército, mientras servía en África.

\section{El Ministro de Obras Públicas impide que los falangistas locales apaleen a los cineastas y los arrojen al río Tajo}

Según sus propias palabras, el denunciante, Luis Infiesta, tuvo que hacer grandes esfuerzos para contenerse y no contestar "adecuadamente" a los que hablaban, iniciando una reyerta. No obstante, al día siguiente se entrevistó con su camarada falangista Cecilio López $\mathrm{Agudo}^{9}$, al que puso en antecedentes de lo que

\footnotetext{
${ }^{9}$ El día 12 de mayo siguiente, Cecilio López Agudo, agricultor, de 38 años de edad, soltero, declarará ante el juez instructor militar y confirmará la existencia de la reunión, pero dirá que no recuerda exactamente las frases. Eso sí, según Cecilio, Luis Infiesta le dijo que los cineastas "habían estado hablando en plan comunista y en contra del ejército". Sin embargo, este enérgico falangista dejará bien claro que se mostró dispuesto a ayudar a Infiesta a dar un castigo a los ahora detenidos. Hay alguna
} 
había pasado. Infiesta pensó que, junto con éste y otros conmilitones, podía intentar entablar conversación con los supuestos desafectos para pillarlos "con las manos en la masa, con testigos presenciales". En tal caso, los planes de Infiesta eran bien sencillos: si era preciso, se podría, sin más trámite, "darles una paliza y tirarlos al río".

Al parecer, estos contundentes proyectos iban en serio porque, ese mismo día, Luis Infiesta contó lo sucedido nada menos que al ministro de Obras Públicas (Alfonso Peña Boeuf) que se encontraba en Aranjuez y con el que le unía una gran amistad ${ }^{10}$. El Ministro, sin duda menos exaltado que los falangistas locales, prohibió terminantemente a Infiesta seguir adelante con sus expeditivos planes y le ordenó que Ilamase inmediatamente al cuartel de la Guardia Civil para presentar la correspondiente denuncia.

El capitán de la Guardia Civil de Aranjuez, Luis Castro Samaniego, confirmó posteriormente que el señor Infiesta, "indignadísimo, quiso ponerse de acuerdo con varios vecinos de esta localidad (para) dejar castigada la frescura con que hablaron" los implicados. Afortunadamente, sus intenciones no se tradujeron en hechos.

\section{Los detenidos: un director y un actor famosos, un abogado de dudosos antecedentes aficionado al cine, un modisto contrabandista desconocido, una modista y una excautiva}

En el momento en que sucedieron los hechos que narramos, Florián Rey era un director de cine consagrado. A sus 51 años entre su filmografía podían citarse títulos tan conocidos como El cura de aldea (Florián Rey, 1926), La Hermana San Sulpicio (Florián Rey, 1927), La aldea maldita (Florián Rey, 1930), Nobleza baturra (Florián Rey, 1935), o Morena Clara (Florián Rey, 1936) ${ }^{11}$.

Los informes llegados al instructor militar daban cuenta de la buena conducta moral pública y privada del famoso director y reconocían que se desconocía que

confusión con el nombre de este personaje, ya que Luis Infiesta se refirió inicialmente a Cecilio Ruano.

${ }^{10}$ El ministro tenía una casa en Aranjuez.

${ }^{11}$ Fernando MÉNDEZ-LEITE, Historia del cine español. Tomos / y II, Editorial Rialp, Madrid, 1965. 
hubiese pertenecido a partidos políticos y organizaciones del Frente Popular ${ }^{12}$. Florián Rey estaba conceptuado como respetuoso y entusiasta con el Glorioso Movimiento Nacional.

El actor Miguel Ligero tenía entonces 58 años, estaba casado y era por aquellas fechas un conocido cómico protagonista de diversas películas de gran éxito. El inicio de la guerra le sorprendió en la zona republicana y allí actuó en diversos festivales. No obstante, logró salir de la España republicana en septiembre de 1936 y marchó a Cuba, Méjico, París y Berlín, para rodar varias películas. Según los informes disponibles, Miguel Ligero regresó a España en 1938 y fijó su residencia en Sevilla.

Los informes políticos-sociales que llegaron al instructor militar sobre Miguel Ligero daban cuenta de una actitud respetuosa y entusiasta hacia el Glorioso Movimiento Nacional y de una buena conducta moral pública y privada. En estos documentos se afirma que había "tenido siempre buen comportamiento con sus convecinos, que le consideran como persona de orden y de buena formación religiosa". Los informes avisaban de que Miguel Ligero estaba bien relacionado con personas solventes y acreditadas y de que había actuado en beneficio de las tropas nacionales ${ }^{13}$.

Tanto Florián Rey como Imperio Argentina y Miguel Ligero fueron considerados durante la guerra como traidores a la República por su abierta colaboración con el bando franquista ${ }^{14}$.

\footnotetext{
${ }^{12}$ Sin embargo, el expediente policial a nombre de Antonio Martínez del Castillo explicaba que, unos meses antes de iniciarse la guerra, "se afilió a UGT pero sin fin partidista sino meramente circunstancial, por pertenecer al Sindicato de Películas, no conociéndosele ninguna actividad destacada dentro de la citada sindical marxista" Archivo General de la Administración, expediente policial de Antonio Martínez del Castillo (Florián Rey), legajo número 573/20.

${ }^{13}$ Miguel Ligero presentó un certificado expedido por el Capitán General de la Primera Región Militar en el que se aclaraba que su situación militar era la de pase a segunda situación de servicio activo. En este certificado se explicaba que el 30 de junio de 1909 se le instruyó un expediente por deserción, pero le fueron concedidos los beneficios de la Ley de 6 de mayo de 1918, habiéndose redimido, con fecha 3 de julio de 1935, a metálico por valor de 1500 pesetas, cantidad nada despreciable para la época.

${ }^{14}$ De hecho, poco antes del alzamiento, Florián Rey había protagonizado un sonado incidente con el Subsecretario de Industria y Comercio nombrado por el Frente Popular. El día 6 de junio de 1936, se celebraba un banquete en honor del periodista cinematográfico Juan Antonio Cabero. El Subsecretario de Industria y Comercio hizo uso de la palabra para prometer el apoyo del Gobierno a la industria cinematográfica española, considerando un deber esa protección. El diario $A B C$ narra así lo sucedido: "En tal punto interrumpe Florián Rey para decir que hasta la fecha todo se vuelven promesas, sin que la realidad se haya hecho jamás tangible después de ningún discurso. Con tal motivo se produce un considerable barullo, en el que nadie se entiende. Calmados los ánimos, al parecer, se intentan
} 
Rogelio Periquet Rufilanchas era un abogado amante del cine y del teatro. De hecho, en 1925 había dirigido una película, Odio de razas (Rogelio Periquet, 1925), que se ha perdido ${ }^{15}$. Su padre (Fernando Periquet) era el letrista de Enrique Granados. En 1942 había colaborado en la redacción del guión de la película Goyescas, (Benito Perojo, 1942) ${ }^{16}$ y en 1943 había estrenado la obra teatral Primavera de vejez (Rogelio Periquet, 1943) ${ }^{17}$. En el momento en que sucedieron los hechos, Rogelio Periquet tenía 42 años.

Aunque Periquet Rufilanchas era un reconocido y ferviente derechista, sus antecedentes eran dudosos, incluso desde la óptica de los vencedores. Este abogado pasó la guerra en el Madrid republicano, donde tuvo diversos problemas con la justicia, ya que fue detenido varias veces por desafección y otros delitos contra la República y pasó por diversas cárceles. Según parece, había sido acusado de estafar a refugiados pro-nacionales de la Embajada de Panamá durante la Guerra Civil. Periquet fue uno de los abogados defensores en uno de los procesos más célebres contra organizaciones de la Quinta Columna franquista madrileña: el conocido como "de los 195", por el elevado número de acusados. Los informes político-sociales que llegaron al instructor militar dibujaban un perfil en términos "rotundamente desfavorables, por su conducta equívoca, sus negocios turbios, sus excesos y francachelas con personajes marxistas que enmarcan su actuación en repugnante contraste con la tragedia que asoló a España, sin base ideológica firme y con sentido de despreocupada frivolidad alimentando sus ambiciones de arribista y vividor" ${ }^{18}$. El informe que Falange hizo llegar

inútilmente las rectificaciones. Hay gritos, protestas y vítores. Las señoras y señoritas que asisten al acto se levantan y abandonan el local" $A B C$-Madrid, 7 de junio de 1936, pág 63. Este incidente tuvo gran repercusión. De hecho, se rumoreó que el Gobierno estaba pensando sancionar a Florián Rey prohibiendo la proyección de sus películas. Para evitar lo cual, una comisión de redactores cinematográficos encabezada por su presidente, Arturo Pérez Camarero y por el decano Juan Antonio Cabero, visitó al Director General de Industria para hacerle ver que la sanción no alcanzaría a Florián Rey, ya que el director había cobrado sus trabajos y pesaría sobre la productora CIFESA. El Director de Industria se comprometió a no actuar a la ligera La Libertad, 9 de junio de 1936, pág. 6.

15 Eduardo GARCIA ROJAS, "El ladrón de los guantes blancos cumple 90 años", recuperado de http://www.elescobillon.com/2016/02/el-ladron-de-los-guantes-blancos-cumple-90-anos/ 2016 , (consultado el 24 de febrero de 2017).

${ }^{16}$ Agustín RUBIO ALCOVER, "Pionerismo relativo y autoría compartida. Mito contra Historia del cine español". Historia y Comunicación Social, 18, (2013) octubre, 307-316.

${ }^{17}$ ABC-Madrid, 13 de marzo de 1943, página 11.

${ }^{18}$ El expediente policial de Rogelio Periquet Rufilanchas era ciertamente notable. En las diligencias figura un informe de la Dirección General de Seguridad con los siguientes antecedentes: el 14 de septiembre de 1935 había sido denunciado por amenazas de muerte; el 26 de septiembre de 1936 
al instructor afirmaba que estaba "mal conceptuado en su vida pública y privada" y que eran "corrientes los casos de inmoralidad manifiesta en el ejercicio de su profesión".

Teresa Giralt Gómez era la más joven del grupo. Contaba entonces con 29 años de edad y era esposa o pareja de Rogelio Periquet Rufilanchas. Como profesión declaró la muy habitual entonces de "sus labores". María Teresa Giralt había compartido algunas de las vicisitudes de Rogelio Periquet durante la guerra civil. De hecho, había sido detenida por los republicanos y tenía la condición de excautiva. La Guardia Civil sabía que había sido liberada por mediación de la embajada de Cuba, ya que tenía la nacionalidad de aquel país. La Benemérita le achacaba "mala conducta moral y pública".

Evaristo González Aguilar tenía 36 años de edad, estaba soltero y era modisto. Había pertenecido a UGT antes de la guerra, pero se había afiliado a la CNT durante la misma para trabajar de camarero en Madrid. Se incorporó al ejército republicano y permaneció en él hasta junio de 1938. Entonces logró pasarse a la zona nacional y sirvió allí hasta mayo de 1939. La policía pensaba que tenía buena conducta moral pública y privada y estaba considerado como persona de orden y sin ideas políticas, siendo "indiferente al Glorioso Movimiento Nacional". A pesar de los informes anteriores, la Policía sabía que había sido detenido en 1944 por contrabando y estuvo en prisión por ello ${ }^{19}$.

\footnotetext{
llevaba un mes detenido a consecuencia de un registro efectuado en su domicilio en el que se encontraron diversas armas y cartuchos; el 8 de abril de 1937 presentó denuncia en la comisaría de Buenavista, alegando que había sido detenido contra su voluntad en la Legación de Panamá, pero las averiguaciones practicadas pusieron de manifiesto que cobraba dinero a los allí refugiados; el 18 de agosto de 1938 un juzgado interesó su paradero por estafa; el 12 de febrero de 1940 la Auditoría del Ejército de Ocupación de Madrid expidió un certificado dando cuenta de que había sido absuelto por no concretarse suficientemente su responsabilidad criminal, pero estimaba que concurrían motivos para que el acusado fuese apartado de su actividad profesional como abogado; el 28 de febrero de 1940 fue puesto en libertad, pero confinado en La Coruña; el 24 de abril de 1940 la Auditoría de Guerra del Cuerpo de Ejército de Guadarrama interesó su detención por haberse fugado de La Coruña; el 6 de julio de 1940 fue detenido e ingresado en la prisión provincial de Comendadoras, aunque sería posteriormente liberado; el 14 de diciembre de 1940 fue detenido y puesto a disposición del juzgado de guardia de Madrid por haber ofrecido la libertad a un detenido a cambio de 10000 pesetas; el 13 de febrero de 1940 fue nuevamente detenido por haber sido denunciado como autor de la desaparición de un baúl que le fue confiado durante la "dominación roja" en Madrid, pero fue puesto en libertad el 31 de diciembre de 1941.

${ }^{19}$ Además, el 15 de enero de 1929 el diario La Voz informaba de una estafa a la Compañía de Madrid, Zaragoza y Alicante, cometida por Evaristo González Aguilar y otros dos acusados más La Voz, 15 de enero de 1929, pág. 10.
} 
Según los informes recibidos, Monique Beltrán desarrollaba una intachable conducta moral, pública y privada y era adepta a la Causa Nacional. Monique Beltrán tenía 33 años de $\operatorname{edad}^{20} y$, a pesar de su nombre, era natural de San Sebastián. La Guardia Civil, más circunspecta, se mostraba algo más crítica con Monique. Según el informe enviado al instructor militar, "hacía vida marital" con Evaristo, individuo "que merece mal concepto". En su declaración ante el instructor militar, Monique Beltrán declaró que era modista.

\section{El denunciante: un amante del cine con dudosos antecedentes}

Luis Infiesta Rojas, el denunciante, tenía entonces 42 años de edad, estaba casado y era industrial. Infiesta era un militante de Falange Española Tradicionalista de las Juntas de Ofensiva Nacional Sindicalistas (FET-JONS). Empezó muy joven como actor de teatro en España y Argentina. Según sus declaraciones a un periódico en 1927, intentó el salto a la fama en Los Ángeles, pero volvió desencantado al ver la inutilidad de sus esfuerzos "entre aquel número considerable de estrellas de primera magnitud" ${ }^{21}$. Actuó, al parecer, en varias películas, la más conocida es El cura de aldea (Florián Rey, 1926) ${ }^{22}$. Como actor de cine, a finales de los años 20 participó en festivales con el fin de recaudar dinero para la lucha contra la tuberculosis con la película La jura de la bandera, al parecer, dirigida por él mismo ${ }^{23}$. A partir de 1934 fue arrendatario del antiguo Teatro Real Coliseo de Carlos III de Aranjuez ${ }^{24}$.

\footnotetext{
${ }^{20}$ Este dato figura en su declaración ante los inspectores de policía enviados al cuartel de la Guardia Civil de Aranjuez. En su declaración del día 3 de mayo ante el juez instructor militar, en el apartado correspondiente a la edad, sólo figura el dato de que era "mayor de edad".

${ }^{21}$ El Heraldo Alavés, 22 de julio de 1927, página 1.

${ }^{22}$ Fernando MÉNDEZ-LEITE, Historia del cine español. Tomos I y II... Op. Cit.

${ }^{23}$ No hemos hallado mucha información sobre esta película, que presentó como soldado del Regimiento Saboya con acompañamiento de música militar. También habría filmado La hija de nadie, de la cual tampoco hemos encontrado más información. En una película titulada La chica del gato figura un tal Infiesta (sin más datos) como actor Francisco Javier MEDRANO COLL, El cine argumental español durante la dictadura de Primo de Rivera, Tesis Doctoral, Universidad de Barcelona, 2015. También habría participado como actor en las películas Santa Teresa de Jesús y El Cristo de la Vega El Heraldo Alavés, 22 de julio de 1927, página 1.

${ }^{24}$ Francisco NOVALES "El espectáculo continúa", en www.nuevomas.com/2014/06/06/el-espectaculocontinua/ 2014, (consultado el 24 de febrero de 2017).
} 
Luis Infiesta pasó la mayor parte de la guerra civil en territorio controlado por el bando republicano, aunque no luchó en los frentes. Una vez finalizada la contienda fue investigado, sin consecuencias, porque había colaborado con el bando perdedor como speaker con un servicio de altavoces de su propiedad que los republicanos habían instalado en Aranjuez para transmitir noticias a la población ${ }^{25}$. También habría colaborado con los republicanos haciendo propaganda en Toledo para favorecer la rendición de los sitiados en el Alcázar. Esto, desde el punto de vista de los vencedores, ya era más grave, sin duda, que lo anterior. Sin embargo, en la investigación que se abrió al efecto, quedó claro que sus ideas eran más bien contrarias a la causa republicana y que había estado en contacto con la Quinta Columna madrileña. De hecho, había ayudado a varios perseguidos a pasar a la zona nacional. Él mismo huyó a dicha zona a finales de 1938, cuando su quinta fue llamada por el Gobierno de la República, y sirvió en la Policía Militar ${ }^{26}$.

En las diligencias previas que se llevaron a cabo para esclarecer la conducta de Luis Infiesta durante la Guerra Civil figura un informe muy negativo firmado por quien, varios años después, lo consideraría un eficaz confidente: el capitán de la Guardia Civil de Aranjuez Luis Castro Samaniego, autor de las detenciones que nos ocupan ${ }^{27}$. Efectivamente, en el transcurso de las diligencias previas contra Florián Rey y los demás implicados, el capitán Castro, de la Guardia Civil de Aranjuez, explicó en un escrito dirigido al juez instructor militar que tenía montado un servicio en todos los pueblos a su cargo, con personal confidente. El objetivo de este servicio era claro, si bien la gramática de su exposición no lo era tanto: "entrometidos en bares y hoteles,

\footnotetext{
${ }^{25}$ Archivo General Histórico de Defensa, expediente número 24078, legajo 7563.

${ }^{26}$ Centro Documental de la Memoria Histórica, expediente de Luis Infiesta Rojas.

${ }^{27}$ Según dicho informe, fechado el 13 de octubre de 1940, antes del Glorioso Movimiento Nacional, Luis Infiesta se manifestó como elemento de izquierdas. Como empresario de espectáculos públicos "siempre procuró poner en escena obras de carácter marxista". Durante la guerra, mediante unos altavoces instalados en el Ayuntamiento, "alentaba a las masas marxistas para que defendieran a todo trance la causa roja". Marchó a Toledo para hacer propaganda con el fin de conseguir la rendición de los sitiados en el Alcázar. Luis Infiesta se habría instalado en la Plaza de Zocodover, donde había trasladado sus altavoces y "por ellos se dirigió a los defensores del Alcázar invitándoles a la rendición, porque, según él, no tenían salvación". Al ser liberado Toledo, huyó, dejando los altavoces, pero trajo algunos fusiles y correajes abandonados por los milicianos. Según el informe, Luis Infiesta decía que traía los fusiles "para que no cayeran en poder de los facciosos", al mismo tiempo que trataba de cobardes a quienes los habían abandonado. Posteriormente se trasladó a Madrid y requisó otros altavoces y continuó con ellos su labor de propaganda. El informe reconoce que, a fines del año 1938, Infiesta se pasó a la zona nacional Archivo General Histórico de Defensa, expediente número 24078, legajo 7563.
} 
comprueben de una manera clara aquel personal de la anti-España que lanzan (sic) bulos y tienen conversaciones que atacan directamente contra la seguridad del Estado". Según el capitán Castro, "dicho señor Infiesta ... me prestó buenos servicios, dando siempre resultado las denuncias reservadas que se me han hecho". Como podemos comprobar, se había producido un cambio radical en la opinión del capitán Luis Castro Samaniego acerca del industrial Luis Infiesta Rojas desde el informe negativo de 1940 a los encendidos elogios de 1945.

En su declaración ante la Guardia Civil a raíz de su detención, Florián Rey se refirió a Infiesta como un "antiguo amigo suyo" al que invitó a sentarse con los demás comensales. Dado que "hacía muchos años que no se habían visto, recordaron todas las vicisitudes pasadas por ambos durante toda esta época, haciendo casi constantemente uso de la palabra el (sic) Infiesta".

\section{El capitán de la Guardia Civil: un oficial conocido por su mano dura}

El capitán Luis Castro Samaniego había nacido en Espejo (Córdoba) en mayo de 1894. En julio de 1915 había ingresado en el ejército como soldado de infantería "voluntario con premio". Estuvo destinado en África y allí participó en diversos combates. Poco a poco fue subiendo en el escalafón militar y en marzo de 1934 ingresó en la Guardia Civil ya como teniente ${ }^{28}$. Este oficial había estado destinado antes de la guerra en Lucena (Córdoba). Allí era conocido como "Teniente Polvorilla". Tuvo un papel relevante tanto en el alzamiento en aquella localidad, como en la represión posterior. Una de sus contribuciones en este terreno fue la creación del Escuadrón de Caballistas Aracelitanos, conocido popularmente como el "Escuadrón de la Muerte" ${ }^{29}$. Al mando de diversas unidades, Luis Castro Samaniego participó en operaciones "de policía y limpieza" contra huidos y fuerzas irregulares. En su hoja de servicios personal figuran varias condecoraciones y algunas referencias a procesos incoados de los que salió absuelto.

\footnotetext{
${ }^{28}$ Archivo Histórico de la Guardia Civil, hoja de servicios de Luis Castro Samaniego.

${ }^{29}$ Arcángel BEDMAR, República, guerra y represión. Lucena 1931-1939, Lucena, Ayuntamiento de Lucena: Lucena, 2000.
} 
No parece que el capitán Castro tuviese muchos escrúpulos a la hora de detener a personas relacionadas con el mundo del cine. De hecho, el incidente que nos ocupa no fue el primer tropiezo que el oficial tuvo con esa industria. En abril de 1943 el auditor militar había ordenado que se abriesen diligencias para esclarecer las circunstancias en que dos empleados de los Estudios Cinematográficos de Aranjuez habían sido detenidos sin muchos miramientos $\mathrm{y}$, al parecer, maltratados por Castro Samaniego. Según rezan los documentos, el capitán sospechaba que estos dos trabajadores cinematográficos habían estado murmurando que él perseguía o se entendía con la esposa del director de los estudios, así como que vivía maritalmente, sin estar casado, con ella ${ }^{30}$. Los dos detenidos le acusaron de haberlos tenido incomunicados a causa de lo que, a todas luces, parece una cuestión menor y de haberles maltratado de "palabra y obra" para que declarasen que ellos eran los autores de esos rumores.

\section{El juez instructor militar: un oficial de caballería que había tenido algún tropiezo con la justicia militar}

Se encargó del caso el comandante de caballería Alejandro Nieto Gómez, del Juzgado Militar permanente número 29, sito en la calle del Piamonte número 2 de Madrid $^{31}$. Al igual que el capitán Castro Samaniego, el comandante Nieto Gómez tenía una larga trayectoria en el ejército. Nacido en octubre de 1889, había ingresado como recluta en el ejército en $1910^{32}$.En 1931 era teniente de caballería por antigüedad. EI inicio de la Guerra Civil le sorprendió en El Ferrol desempeñando el cargo de juez militar. Se puso a disposición de los alzados y el día 22 de julio empezó a actuar como juez en las causas que se originaron por los sucesos que tuvieron lugar en aquella plaza durante la sublevación militar. Posteriormente, en noviembre de aquel año fue destinado a formar parte de los tribunales militares de la Auditoría del Ejército de Ocupación. El comandante Nieto desempeñó su labor en Talavera de la Reina y en la columna de orden y policía de Madrid.

\footnotetext{
${ }^{30}$ Archivo General Histórico de Defensa, expediente número 120141, legajo 5397.

${ }^{31}$ En ese edificio había estado anteriormente la Casa del Pueblo de Madrid.

${ }^{32}$ Archivo General Militar de Segovia, hoja de servicios de Alejandro Nieto Gómez.
} 
En julio de 1938 se vio envuelto en unas diligencias previas para esclarecer su actuación en relación con ciertas deudas contraídas ${ }^{33}$. Una vez finalizado el conflicto ocupó diversos destinos, incluido Larache. En abril de 1945 fue destinado al Juzgado Militar número 29 de Madrid, donde, nada más llegar, tuvo que lidiar con el asunto de los cineastas detenidos.

\section{Se pone en marcha la maquinaria burocrática del proceso militar}

Los detenidos hicieron sus primeras declaraciones ante la Guardia Civil de Aranjuez, es de suponer que sin contar con asistencia letrada. La versión que ofrecieron fue harto diferente a la que presentó el denunciante, Luis Infiesta. Así, Miguel Ligero afirmó que era "absolutamente incierto que haya pronunciado frases injuriosas contra nuestro ejército, ni haya dicho nada en relación con el ejército americano". Según su versión, solamente conversó del cine mudo durante largo tiempo y luego "le entró sueño" y "estuvo adormilado" durante el resto de la conversación.

El director Florián Rey dijo que no recordaba que durante la conversación se hablase de política, ni se hicieran manifestaciones en relación con la actual contienda. Además, afirmó que no era cierto que Miguel Ligero hiciera afirmaciones derrotistas. Todavía a estas alturas, Florián Rey dijo que desconocía quién podía ser el denunciante. Por su parte, Evaristo González Aguilar, Monique Beltrán Broussoux, Rogelio Periquet Rufilanchas y María Teresa Giralt Gómez también negaron que se hiciera mención alguna al ejército español y afirmaron que no se pronunciaron palabras ofensivas en su contra, ni contra el actual Régimen. Además, María Teresa Giralt afirmó muy vehementemente que era "absolutamente incierto que haya dicho que Rusia tendría derecho a exigir represalias por haber enviado España la División Azul a combatir contra ellos" ya que "ni siquiera tiene idea que durante toda la conversación desarrollada esa noche se hablase para nada de Rusia ni de la División Azul".

Las protestas anteriores no sirvieron de mucho, ya que todas las diligencias previas fueron enviadas el 3 de mayo al juez instructor, militar, por supuesto. Ese

\footnotetext{
${ }^{33}$ Archivo General Histórico de Defensa, expediente número 2140, legajo 1098/15.
} 
mismo día, el agente de policía José Tellaeche Perrín ${ }^{34}$, afecto a la comisaría de Centro, condujo al juzgado militar de guardia a los detenidos en virtud de la diligencia 1865 de la Brigada Social, comprometiéndose a su debida vigilancia hasta la entrega al juzgado citado ${ }^{35}$.

El instructor militar, como sabemos, el comandante Alejandro Nieto Gómez, decretó inmediatamente el ingreso en prisión de todos los varones encausados. Los cuales fueron enviados a la que, con el tiempo, sería tristemente célebre cárcel de Carabanchel. Monique Beltrán y María Teresa Giralt, por su parte, dieron con sus huesos en la prisión de mujeres. Entre los días 3 y 7 de mayo el juez instructor tomó declaración a los encausados, a los testigos que éstos propusieron, al denunciante y a otros testigos. Además, siguiendo el protocolo habitual en estos casos, se solicitaron informes a la Policía, Guardia Civil y a Falange Española sobre la conducta político social de los arrestados.

En aquellos tiempos no era ninguna tontería verse frente a un proceso militar por una acusación tal como la de desafección al Régimen. Es de suponer que personas tan importantes y bien conectadas, como eran los detenidos, pusiesen en marcha su red de conocidos para conseguir apoyos que terminasen con aquella aparentemente absurda situación.

Todos los inculpados ratificaron ante el juez militar sus declaraciones previas realizadas ante la Guardia Civil en el sentido de que, durante la conversación mantenida por la noche en el hotel Pastor de Aranjuez, no se profirieron frases ofensivas contra ninguna institución. Todos consideraban absurdo que tratasen de calificarles como enemigos de las Instituciones Armadas y del Régimen actual, ya que en la comida solo se habló de la guerra sin trascendencia de ninguna clase, girando el resto de la conversación acerca de temas profesionales. Para corroborar su adhesión al Régimen, cada uno de ellos aportó nombres de personas que podrían dar fe de su buena conducta político social.

\footnotetext{
${ }^{34}$ Volveremos a encontrar el nombre de este agente en las diligencias que realizó el instructor militar, ya que, como veremos, testificó a favor de Evaristo González y Monique Beltrán.

${ }^{35}$ Archivo General de la Administración, expediente policial de Antonio Martínez del Castillo (Florián Rey), legajo número 573/20.
} 
El director Florián Rey ofreció pruebas adicionales de su adhesión a la Causa Nacional, no sólo en España sino desde el extranjero (en unión de la actriz Imperio Argentina), ya que poseía el carnet de Falange. Florián Rey consideraba que la denuncia podría tener su origen en algún tipo de animosidad. En el informe que la Dirección General de Seguridad envió al juez instructor militar el día 12 de junio de 1945, se indicaba que era miembro de la jefatura nacional del Sindicato del Espectáculo.

El actor Miguel Ligero alegó en su defensa que, en diferentes ocasiones, había mantenido conversaciones en el conocido bar Chicote de Madrid con el comandante Fernando Fuertes, de la Casa Militar de Su Excelencia el Generalísimo. Por su parte, María Teresa Giralt Gómez dijo que tenía familiares en el ejército que podían testificar a su favor. Además explicó que "en la época roja" fue perseguida, arrestada e incluso condenada a muerte por hacer el saludo fascista. Evaristo González Aguilar hizo constar que, durante la guerra, se pasó de la zona republicana a la nacional, donde prestó servicios en el ejército.

\section{Diversas personas de cierto relieve declaran a favor de los procesados}

Entre aquellos días de mayo, cuando la derrota por las armas de Alemania se materializaba completamente, diversos personajes más o menos relacionados con el mundo del cine fueron desfilando ante el comandante de caballería Nieto y aportaron declaraciones favorables sobre los acusados. A continuación se resumen los testimonios más destacados:

Luis Francisco Blanco Lavín, conocido productor de cine, explicó que Florián Rey había mostrado su disconformidad con el régimen republicano antes de la guerra, que ingresó en la Falange Española estando en Cuba y que fue recibido por Goebbels y por el mismísimo Führer. Según este testigo, Florián Rey habría declinado trabajar en Méjico en 1939 contestando en un cable lo siguiente: "Mientras Méjico no reconozca Gobierno Franco, imposible trabajar en esa Nación". 
Magdalena Nile del Río, nombre auténtico de la famosa actriz Imperio Argentina ${ }^{36}$, depuso a favor de Florián Rey, a quien consideraba antes, durante y después de la guerra como un ferviente defensor del Generalísimo y del Régimen. La ex esposa de Florián Rey afirmó que no le creía capaz de hacer nada en contra del Régimen ${ }^{37}$. Es interesante tener en cuenta que, en estos momentos, la relaciones entre Imperio Argentina y Florián Rey no eran muy buenas. Ambos habían tenido una disputa por la custodia de su hijo ${ }^{38}$.

Luis Muñoz Lorente, escritor y periodista, afirmó que conocía a Florián Rey desde hacía 20 años y lo consideraba una persona de orden, compenetrado totalmente con todos los ideales derechistas. Según este testigo, Florián era un gran admirador y entusiasta defensor del difunto general Primo de Rivera. Aportó todo lo que pudo al Movimiento Nacional y salió varias veces al extranjero, trayendo divisas al Gobierno Nacional con su trabajo cinematográfico. No lo consideraba capaz de cometer actos contrarios al actual Régimen.

Saturnino Ulargui Moreno, arquitecto y productor de películas, declaró a favor de Miguel Ligero, al cual conocía desde hacía más de 30 años por haberle contratado para hacer películas en la zona nacional tanto durante la guerra como después. Consideraba que era un buen español y nunca le había oído ninguna conversación de matiz político, por lo que no le creía capaz de hacer manifestaciones de ningún género, ni contra el Régimen ni contra ninguna institución del mismo.

Víctor de la Serna y Espina, conocido periodista y escritor, declaró igualmente a favor de Miguel Ligero, a quien consideraba persona absolutamente afecta al Régimen, habiendo demostrado en infinidad de ocasiones la defensa de sus ideales.

\footnotetext{
${ }^{36}$ Imperio Argentina es una actriz bien conocida. Fue la protagonista de los grandes éxitos de Florián Rey. Estuvo casada con Florián Rey en los años 30. La relación entre ambos y su separación posterior fueron algo tormentosas Italo MANZI, "Imperio Argentina", Cuadernos Hispanoamericanos, número 642, diciembre de 2003, 111-124.

${ }^{37}$ En las fechas en que acaecieron los hechos que nos ocupan, Imperio Argentina estaba rodando en Madrid la película Bambú, (José Luis Sáenz de Heredia, 1945) Archivo General de la Administración, AGA,36,03236. Esta película se rodó en los estudios CEA de Madrid hasta el mes de abril Fernando VENTAJAS, "Historia de los rodajes cinematográficos en la provincia de Málaga: los largometrajes de los años 30 y 40". Isla de Arriarán, 18, 185-222, 2006.

${ }^{38}$ Imperio ARGENTINA y Pedro Manuel VILLORA(2001). Malena Clara, Madrid, Temas de Hoy, 2001.
} 
Fernando Fernández de Córdoba, locutor de Radio Nacional ${ }^{39}$, declaró también a favor de Miguel Ligero, íntimo amigo suyo, hombre de orden y totalmente afecto al Movimiento Nacional. Había coincidido con Florián Rey en el rodaje de Agustina de Aragón (Florián Rey, 1929). En el momento de esta declaración era compañero de reparto de Imperio Argentina en el rodaje de la película Bambú (José Luis Sáez de Heredia, 1945) ${ }^{40}$.

Jacinto Guerrero Torres, músico y compositor ${ }^{41}$. Declaró como los anteriores a favor de Miguel Ligero, a quien consideraba "un hombre de extrema derecha" el cual, durante la guerra, se manifestó siempre como defensor de la España de Franco. Después de la contienda, había participado en festivales benéficos. En las tertulias que había tenido con él en el bar Chicote siempre había manifestado su total adhesión al Régimen.

José Tellaeche Perrín, quien, como sabemos, era el agente de policía que había conducido a los detenidos al juzgado de instrucción militar, declaró a favor de Evaristo González Aguilar y Monique Beltrán Broussoux. Este policía dijo que conocía "perfectamente y desde hace mucho tiempo a dicho señor" y que no se podía dudar de la leal adhesión de Evaristo durante la guerra a la Causa Nacional. Además, en conversaciones posteriores siempre había exaltado al Generalísimo y al Régimen. Además, afirmó conocer a Monique Beltrán Broussoux, la cual jamás había insinuado nada referente al Régimen, y que, como modista en San Sebastián, vestía nada menos que a la esposa del Generalísimo.

Federico Moreno Torroba, músico y compositor, declaró a favor de Rogelio Periquet Rufilanchas. Por las conversaciones mantenidas con él, siempre encomió la política seguida por el Generalísimo y el Régimen actual de España. Le consideraba totalmente afecto al Régimen actual.

\footnotetext{
${ }^{39}$ Fernando Fernández de Córdoba estuvo implicado en la sublevación en Córdoba en julio de 1936 Francisco MORENO GÓMEZ, La Guerra Civil en Córdoba, Madrid, Ediciones Alpuerto, 1985. Se dio a conocer como actor en los años de la República. Durante la Guerra Civil fue el lector habitual de los partes de la guerra en Radio Nacional. De hecho, se hizo famoso por aquel en el que se anunciaba su fin el 1 de abril de 1939. En la posguerra fue un conocido actor. Recuperado de http://elpais.com/diario/1982/03/02/cultura/383871610 850215.html, consultado el 24 de febrero de 2017, ABC-Madrid, 3 de marzo de 1982, pág. 34, ABC-Madrid, 4 de julio de 1944, pág. 13.

${ }^{40}$ Fernando MÉNDEZ-LEITE, Historia del cine español. Tomos I y II, Op. Cit.

${ }^{41}$ Se trata del conocido "maestro Guerrero", músico y compositor de zarzuelas.
} 
También testificaron a favor de Rogelio Periquet y María Teresa Giralt diversos militares conocidos de la pareja e incluso el tío de María Teresa. Todos los testimonios coincidían en que nunca les habían oído expresar manifestaciones contrarias al Régimen ni a las instituciones armadas, mostrando su adhesión total e incondicional.

El juez militar también llamó a declarar al dueño del bar y al camarero del hotel Pastor que sirvió a los detenidos en aquella fatídica noche de la conversación. Estos dos testigos aportaron poco a la causa, ya que dijeron que no habían escuchado nada de la conversación en la que supuestamente se menospreció al ejército español. Eso sí, el dueño del hotel, Agustín Fernández Serrano, dijo al juez que Infiesta había comentado que los comensales eran comunistas.

José Fernández Aguayo ${ }^{42}$, casado, de 32 años, operador de cine, depuso el día 4 de mayo y explicó que asistió a la comida en la que se originó todo el problema. Sin embargo, se incorporó tarde y sólo oyó hablar del cine mudo. De hecho, parece ser que Luis Infiesta estaba mostrándose demasiado locuaz, hasta el extremo de que el actor Miguel Ligero comentó con sorna: "Menos mal que está hablando del cine mudo, que si lo hace del sonoro, estamos hasta mañana".

\section{La empresa productora y el juez instructor militar solicitan la libertad de los detenidos}

Mientras la maquinaria de la justicia militar franquista movía papeles y realizaba averiguaciones, en la empresa productora se disparaban todas las alarmas ante la situación creada por la detención del director y del protagonista de la película La Luna vale un millón. El incidente de Aranjuez había retrasado el rodaje de la película y esto ocasionaba, sin duda, importantes pérdidas económicas a la productora. Por tanto, no es de extrañar que el día 4 de mayo, Alfonso Carvajal y Guzmán, ingeniero jefe de los Estudios Chamartín, solicitase por escrito al Capitán General de la Primera Región Militar que Florián Rey y Miguel Ligero fuesen llevados a los estudios, "con la debida custodia", para que pudiesen terminar el trabajo pendiente. Al parecer, en esos

\footnotetext{
42 José Fernández Aguayo figura como operador en el expediente de censura correspondiente a la película La Luna vale un millón (Florián Rey, 1945) Archivo General de la Administración, expediente de censura de la película La Luna vale un millón, caja 36/0324. También aparece en los títulos de crédito de la película.
} 
momentos sólo quedaba un día de rodaje. Esta gestión no dio el resultado apetecido y el día 8 de mayo el citado ingeniero volvió a solicitar un día de libertad para el director y el protagonista de la película.

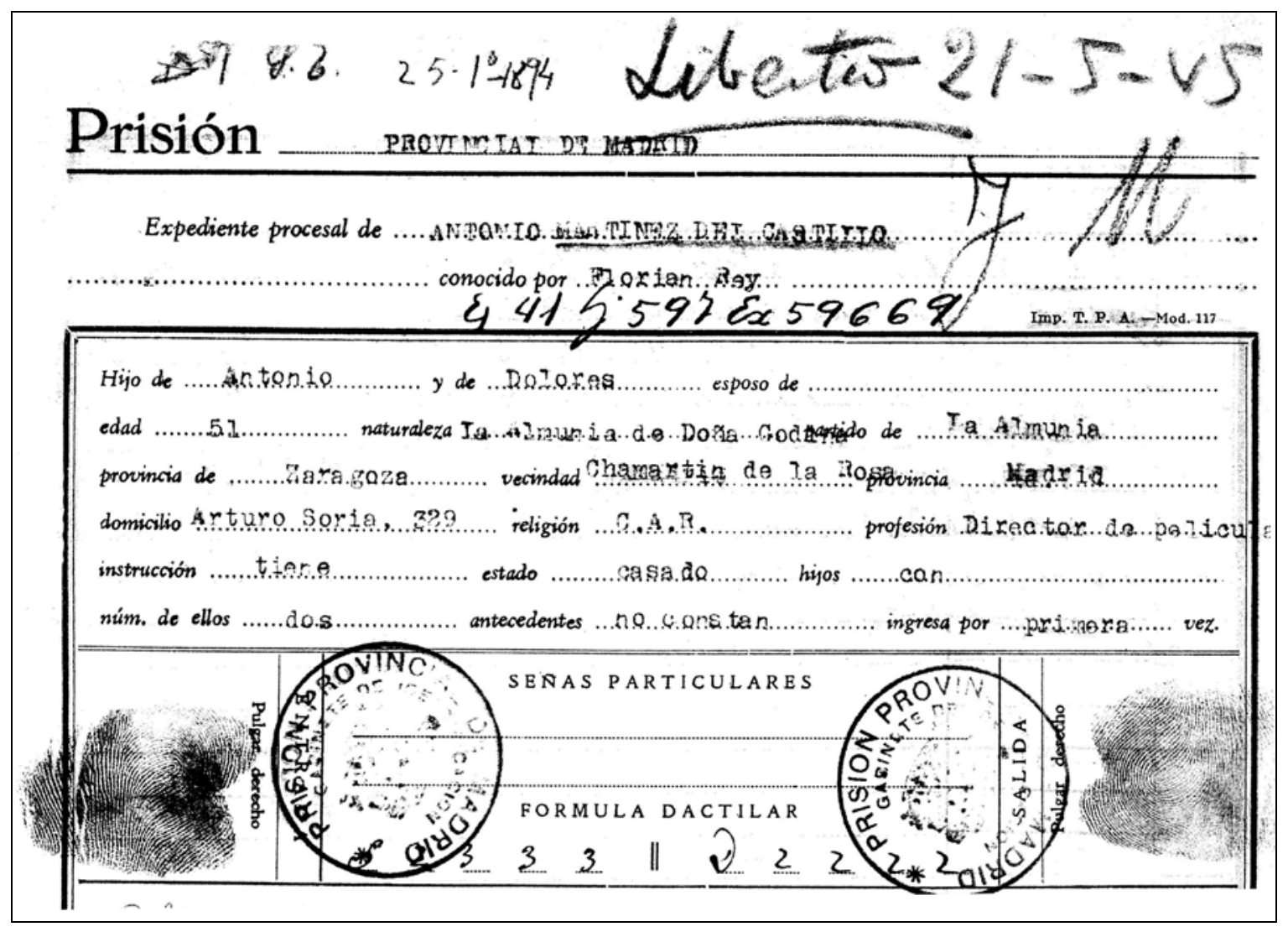

Figura 1: Ficha de prisión de Florián Rey 


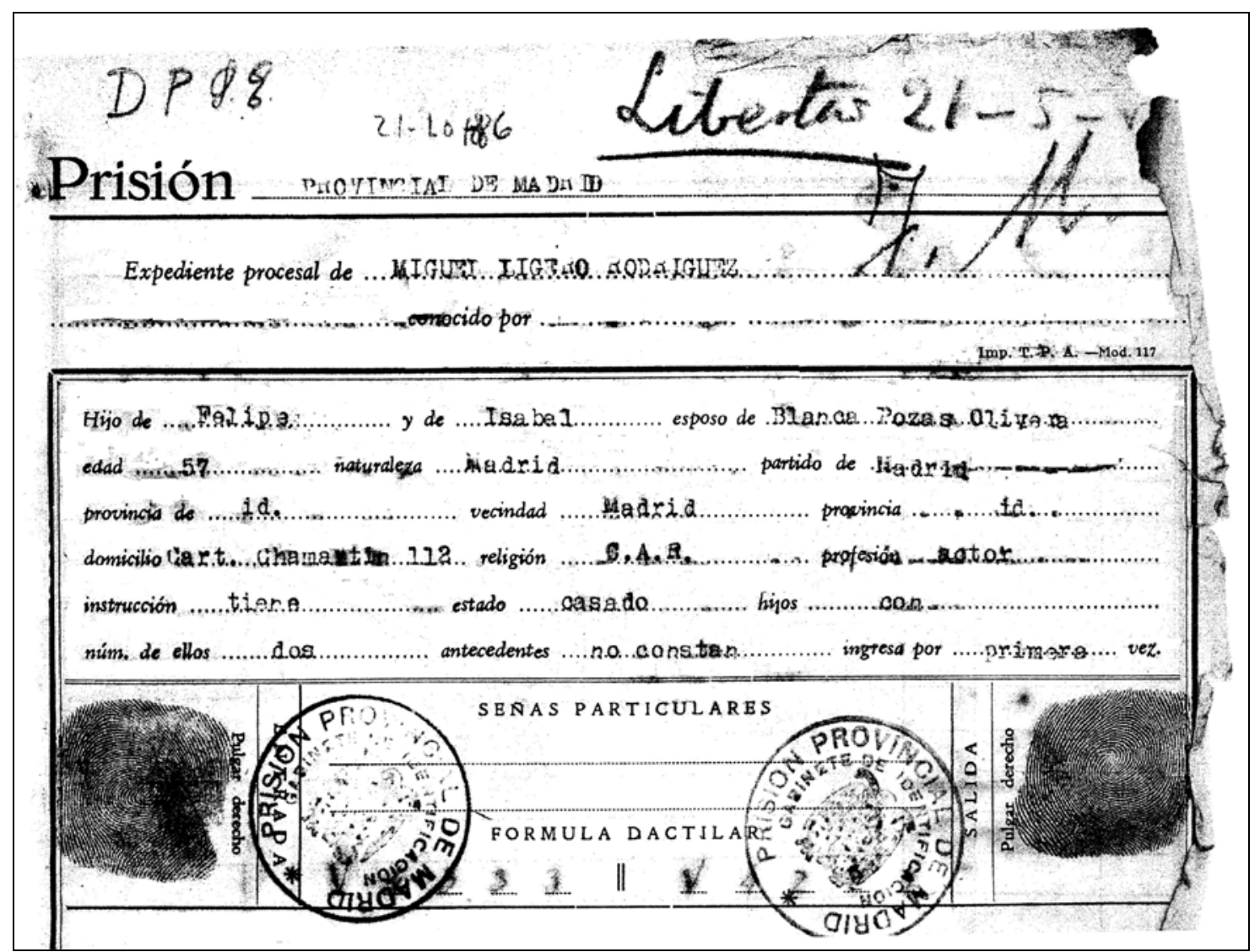

Figura 2: Ficha de prisión de Miguel Ligero 


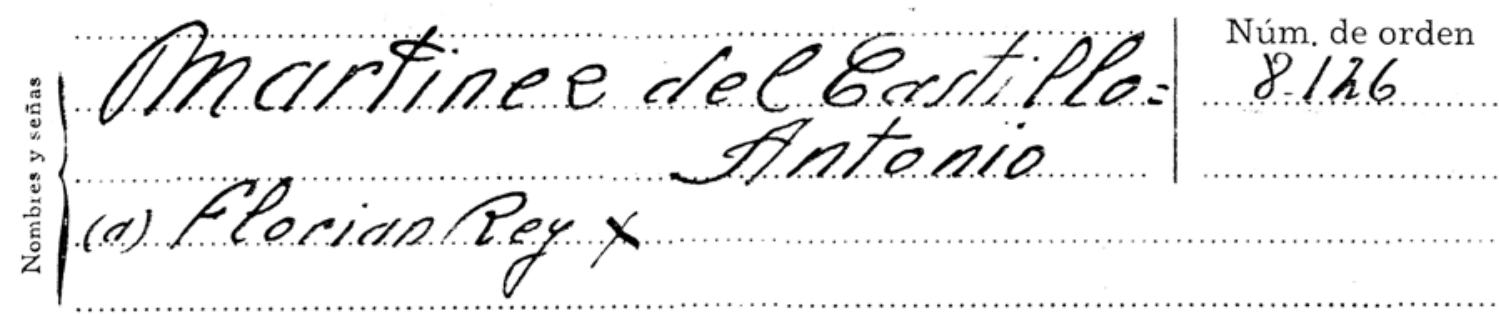

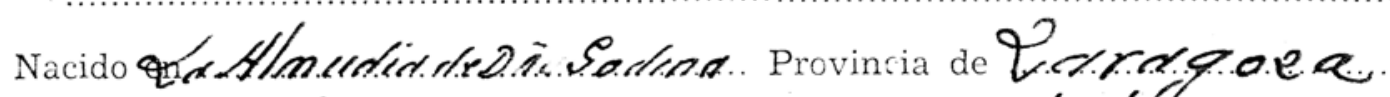

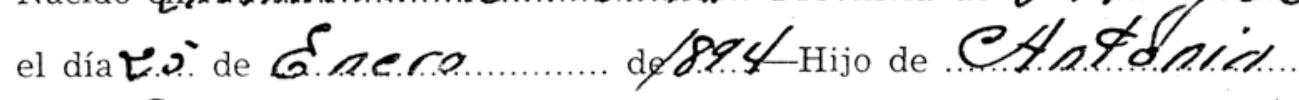

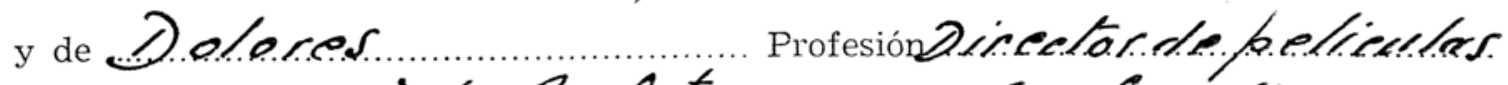

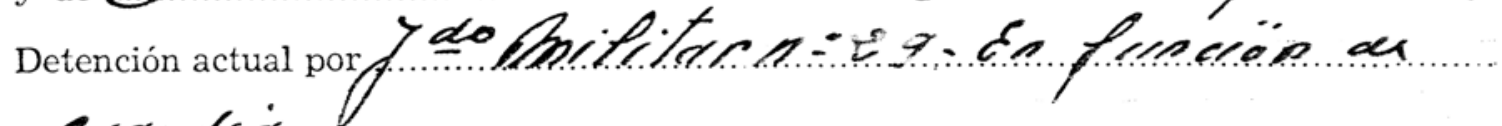
fererorex.

Antecedentes

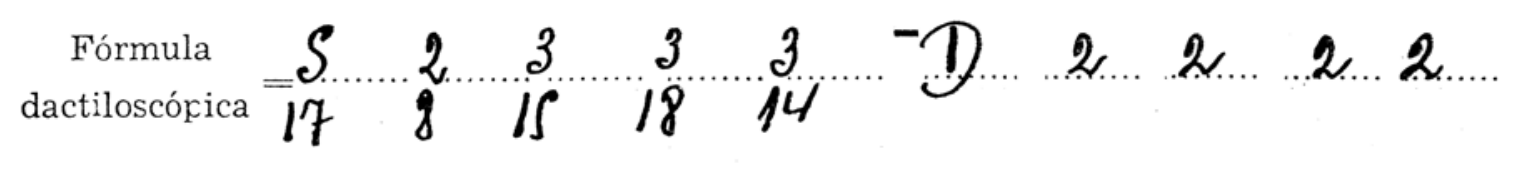

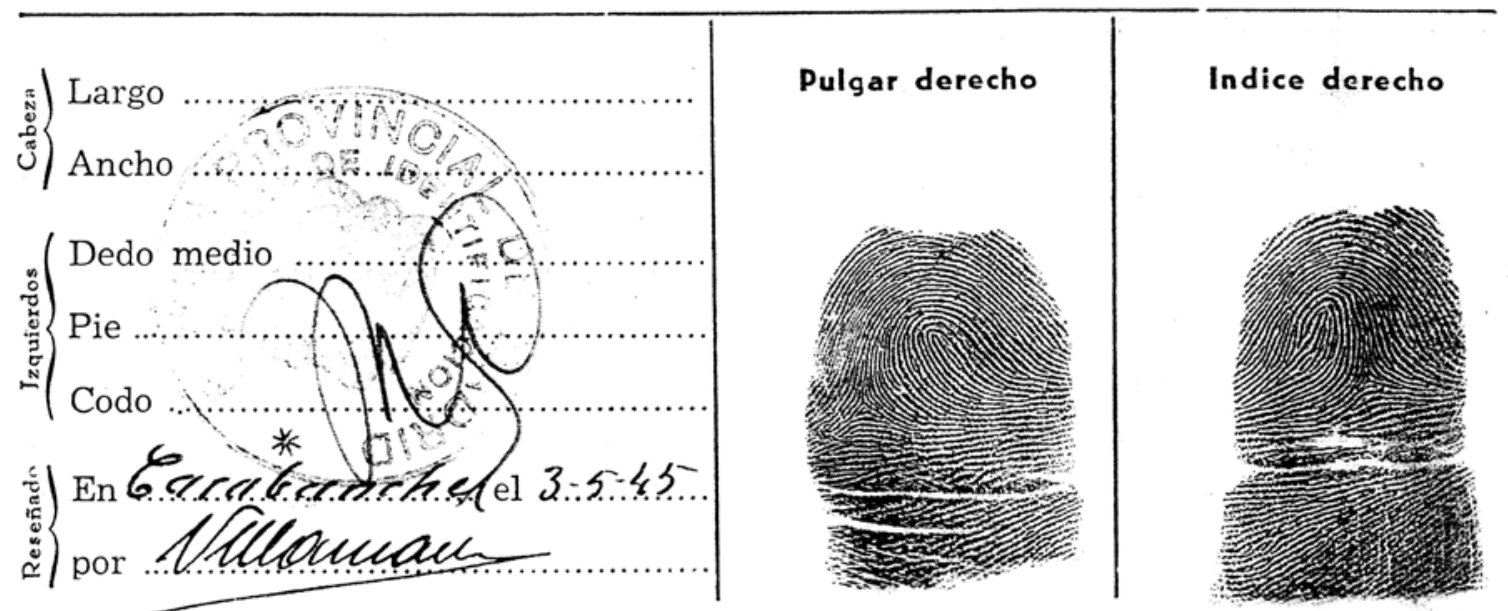

Figura 3: Expediente de prisión de Florián Rehy 


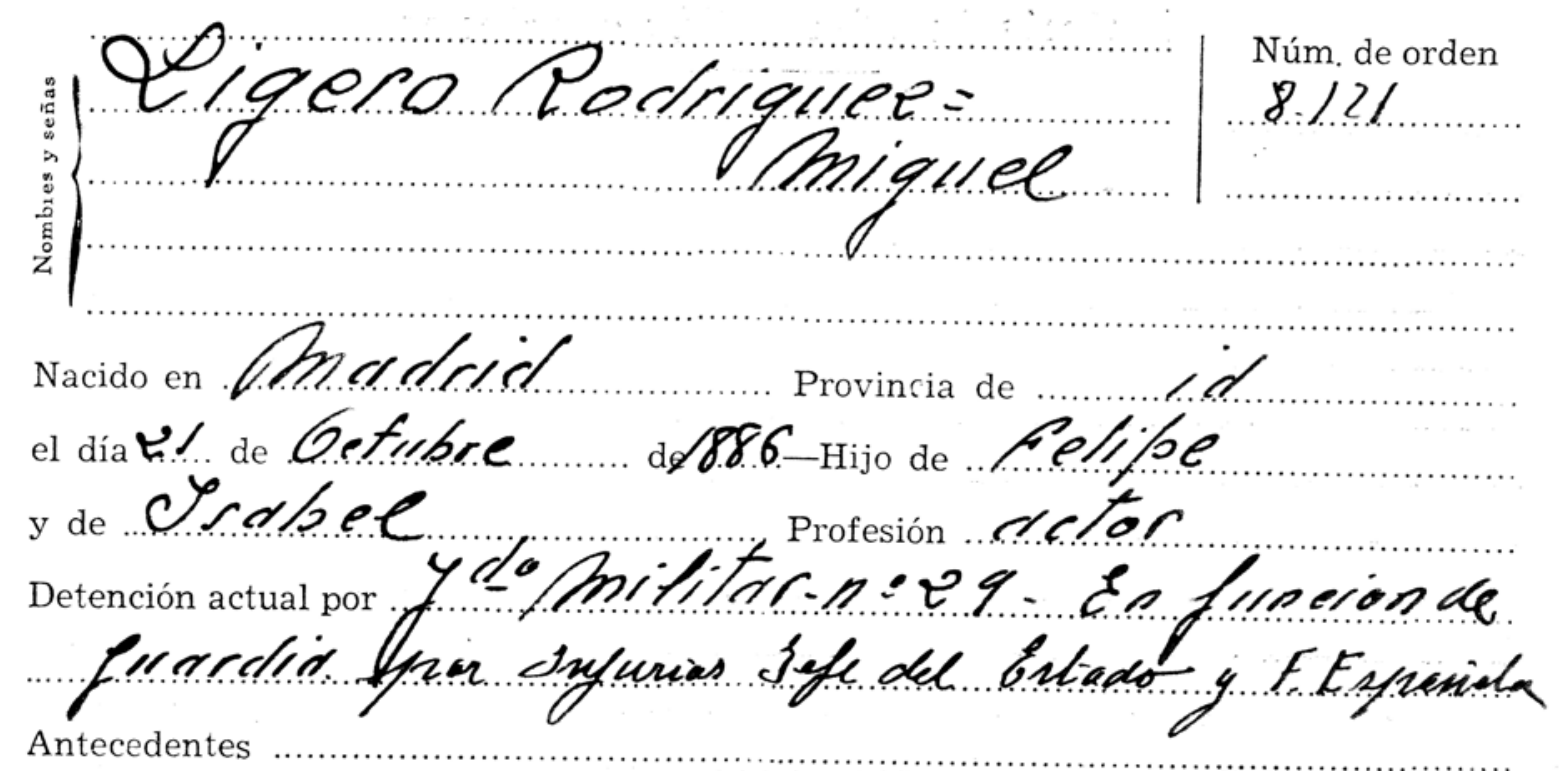

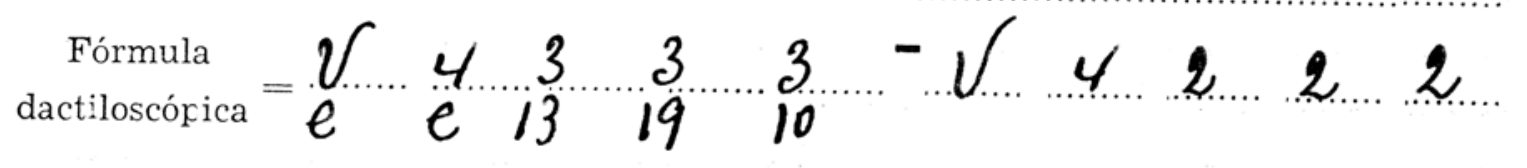

Largo...
İ
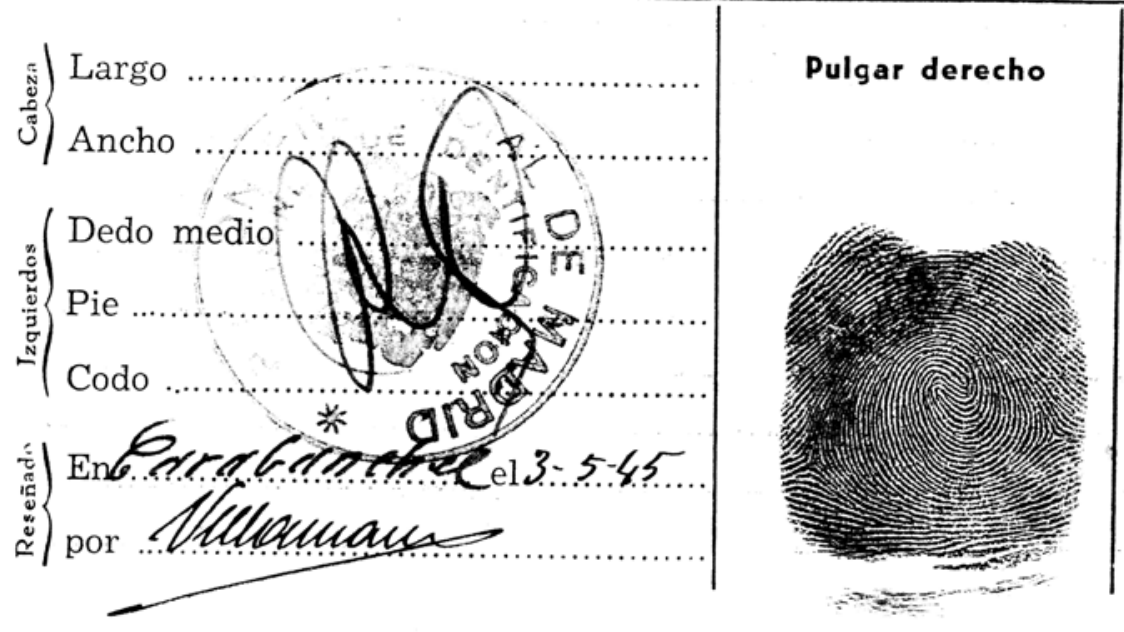

Indice derecho

Figura 4: Expediente de prisión de Miguel Ligero 
El 6 de mayo ya fue el propio juez instructor quien se unió a las peticiones anteriores y, en un escrito dirigido al Auditor de Guerra de la Primera Región Militar, solicitó a su vez la libertad condicional de los encausados, dado que "la pena que pudiera corresponderles, no excedería de la prisión menor". El instructor pensaba que no existían "datos suficientes para elevar a causa el procedimiento". Ante el escaso resultado de esta gestión, el instructor volvió a solicitar el 16 de mayo la libertad de los acusados.

\section{El final del esperpento: libertad para los detenidos y archivo de las diligencias}

Por fin, el 17 de mayo de 1945 el Auditor General acuerda conceder la libertad provisional por no existir datos suficientes para elevar a causa el procedimiento. El 21 de mayo el juez instructor militar decretó la libertad provisional de los encausados aludiendo en su escrito a la solicitud efectuada por el ingeniero jefe de los Estudios Chamartín. Se envió la correspondiente nota de servicio a los directores de las prisiones donde estaban los detenidos. Los encausados fueron puestos en libertad durante los días 21 y 22 de mayo, no sin ser advertidos antes de la obligación de presentarse ante el juez militar. El 23 de mayo el secretario notificó personalmente a cada uno de los encausados el decreto por el que se les concedía la libertad condicional. 


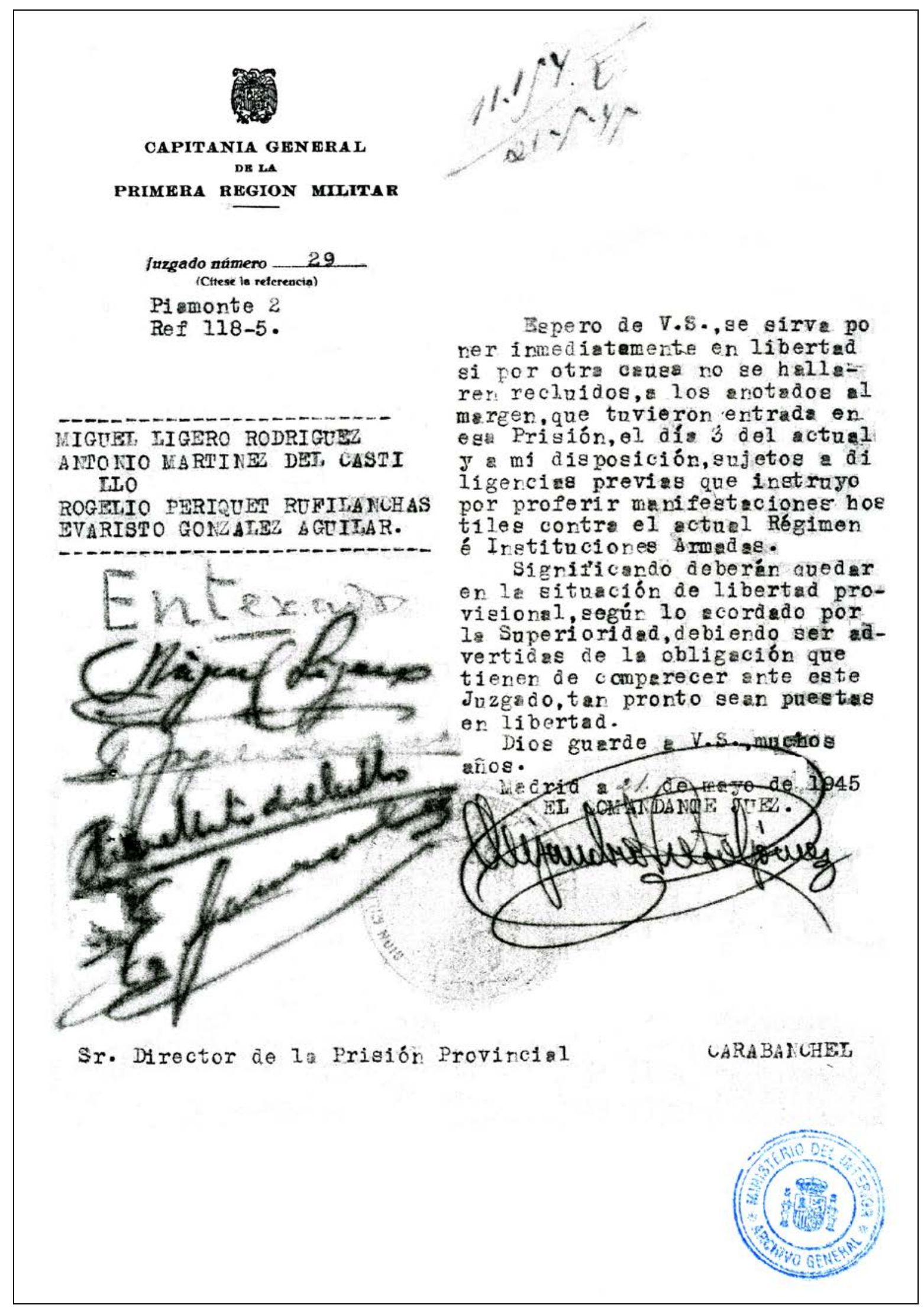

Figura 5: Orden de libertad de los cuatro detenidos varones. La orden aparece firmada por los interesados como "enterados". 
Sin embargo, la liberación no implicaba el fin de las diligencias judiciales. Durante el mes de junio fueron llegando los informes político-sociales solicitados por el instructor militar y estos fueron unidos al sumario. Estos documentos no alteraron esencialmente el curso de la investigación. De hecho, en la diligencia de remisión del procedimiento al Auditor de Guerra, fechada el 4 de agosto de 1945, el comandante Nieto hacía las siguientes consideraciones: "En las declaraciones prestadas ante la Policía, y ante este Juzgado, todos ellos niegan las imputaciones hechas, afirmando con energía su lealtad y adhesión, tanto a S.E. el Generalísimo, como al Régimen y sus Instituciones, lo que corroboran todos cuantos han depuesto en las actuaciones, personas todas ellas de cierto relieve social, las que los presentan como totalmente incondicionales al Régimen actual, en favor del cual contribuyeron durante la guerra de liberación, aportando sus trabajos artísticos y con dinero. Asimismo, les son en extremo favorables los informes de las distintas Autoridades, en relación con la Causa Nacional si bien en los de Periquet y los de González Aguilar constan otros referentes a su vida privada que no afectan al fondo del procedimiento". Se formula "propuesta de libertad por no existir más testigos que el denunciante, el que no pudo citar ningún otro, ya que tanto el dueño del hotel como el camarero no recogieron ni oyeron ninguna de las frases consignadas en la denuncia". En cuanto a la denuncia por deserción contra Miguel Ligero, el juez concluía que, si bien era cierta, "en su día le habían sido concedidos los beneficios de indulto de la Ley de 6 de mayo de 1918". Utilizando una expresión coloquial, estaba claro que no había mucho más que rascar.

El Auditor General examinó las citadas diligencias el día 10 de agosto e informó al Capitán General de la Primera Región Militar que lo pertinente era dar por terminadas las diligencias sin declaración de responsabilidad. El 23 de agosto se le notificó al actor Miguel Ligero la resolución favorable, si bien este acto tuvo que llevarse a cabo en el centro psiquiátrico en el que se hallaba internado ${ }^{43}$. El 1 de septiembre el resto de los interesados recibió la resolución del procedimiento y, es de suponer, todos pudieron respirar, por fin, con cierto alivio.

\footnotetext{
${ }^{43}$ En las diligencias que hemos consultado se conserva un certificado médico oficial según el cual Miguel Ligero Rodríguez había ingresado el día 12 de julio en el sanatorio dirigido por el doctor Enrique de León Benito Chavarri en Madrid. Allí estaba siendo tratado por el coronel médico Antonio Vallejo Nájera.
} 


\section{Una película que pasó sin pena ni gloria}

La película cuyo rodaje fue interrumpido por la intervención de la justicia militar franquista, La Luna vale un millón (Florián Rey, 1945), pasó por las pantallas españolas sin pena ni gloria. De hecho, Agustín Sánchez Vidal la enmarca dentro del periodo que denomina de "decadencia" de Florián Rey ${ }^{44}$.. El título inicial de la película era El pobrecito millonario. Ciertamente, el argumento no era especialmente novedoso. En el Archivo General de la Administración se conservan tanto el expediente de censura ${ }^{45}$, como el de rodaje ${ }^{46}$. Por estos documentos sabemos que la empresa productora era Estudios Chamartín, que actuaba también como distribuidora. La película constaba de 9 rollos con 2700 metros. El argumento era un trabajo de José López Rubio y Luis Marquina. La concienzuda burocracia franquista registró también el número de planos filmados: 103. En el rodaje de los exteriores se habían empleado 9 días en Aranjuez, 2 en la estación de Delicias y 1 en Barajas. La inspección hizo notar en su informe la "gran regularidad y seriedad en el rodaje por obra de su director Florián Rey" ${ }^{47}$.

\footnotetext{
${ }^{44}$ Agustín SÁNCHEZ VIDAL, El cine de Florián Rey, Caja de Ahorros de La Inmaculada, Zaragoza, 1991, pág. 298.

${ }^{45}$ Archivo General de la Administración, expediente de censura de la película La Luna vale un millón, caja 36/0324.

${ }^{46}$ Archivo General de la Administración, expediente de rodaje de la película La Luna vale un millón, caja 36/04674.

${ }^{47}$ Archivo General de la Administración, expediente de rodaje de la película La Luna vale un millón, caja 36/04674, inspección realizada el 5 de marzo de 1945.
} 


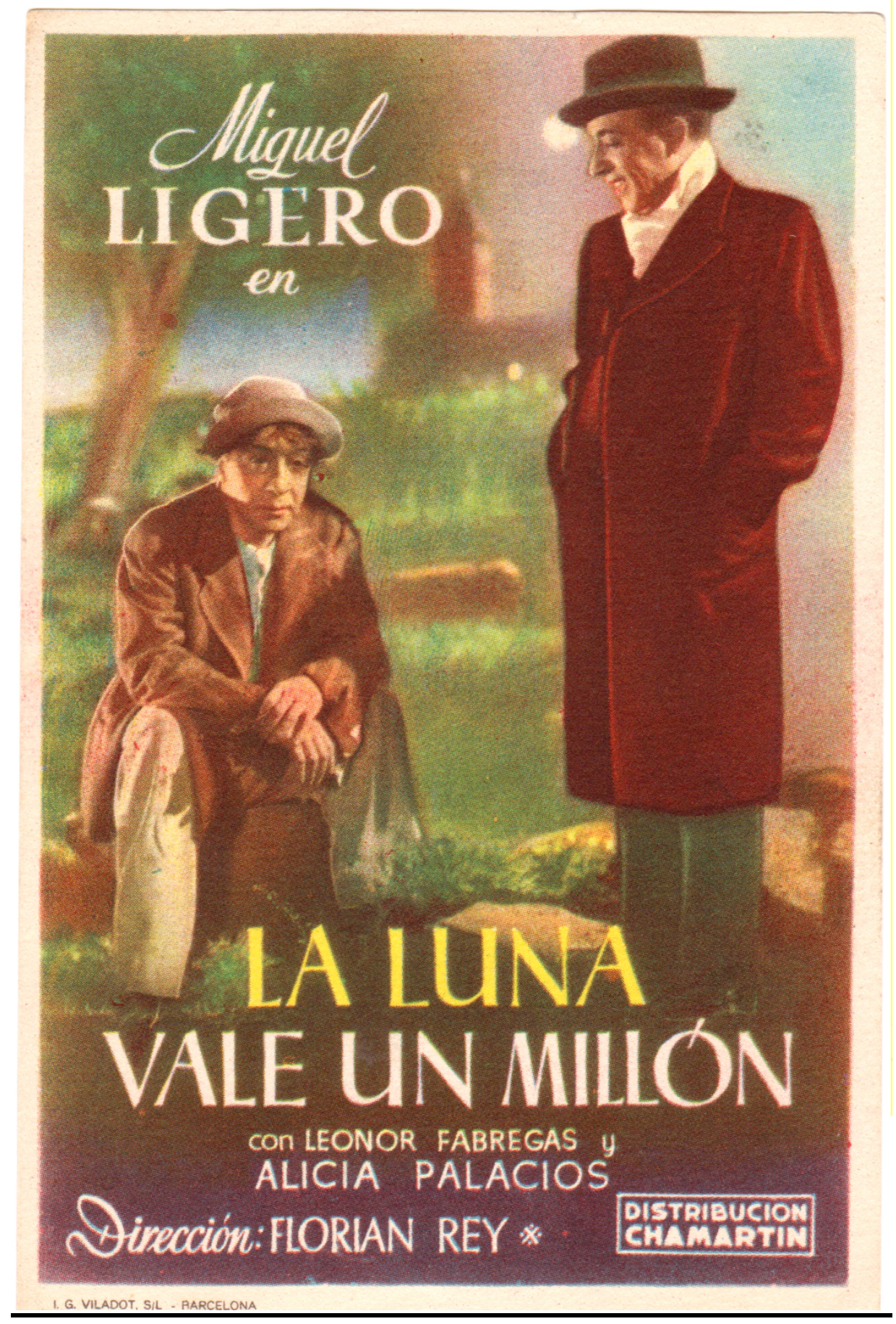

Figura 6: Programa de mano de la película La Luna vale un millón (Florián Rey, 1945 
El permiso de rodaje había sido solicitado por el mismo Florián Rey el 1 de diciembre de 1944, en su calidad de Consejero Técnico de Iberia Films (IFSA) ${ }^{48}$. La autorización tiene fecha de 30 de diciembre. El trabajo se inició el 10 de febrero de 1945 y finalizó, tras la interrupción motivada por los hechos que hemos narrado, el 10 de julio de ese año.

Vale la pena rescatar algunos comentarios de los censores. Como se puede apreciar, se mostraron algo inclementes con el proyecto debido a su escasa calidad artística $^{4950}$.

"Toda la trama de este guión es inverosímil y artificiosa. Los trucos del parecido de dos personas -tan manoseado en el cine- y la sustitución de la una por la otra, es en este caso demasiado forzada. El desenlace sin embargo es ingenioso y original. Si no se exageran demasiado las situaciones y los equívocos pudiera lograrse una película entretenida y graciosa".

"La redacción, por lo menos la copia presentada a censura, está poco cuidada. Obsérvense por ejemplo los pasajes señalados en las páginas 9, 15 y 25.

La escena de la página 49 es demasiado exagerada e inverosímil. Debe cuidarse la redacción de las escenas en el campo (pág. 82 y siguientes) para evitar sugerencias o planos que ofrezcan reparos morales. Tachaduras páginas 82-8990-105-113-125-148-149".

"Película española que pudo ser una cosa fina y humorística, dentro de la inverosimilitud de su argumento, pero que ha resultado una patochada por la exageración y astracanada de Miguel Ligero" (firmado al dorso por alguien como Julio o Julián).

"Una astracanada que por mi parte no considero nada graciosa. Es pena porque podía haberse realizado este guión con fondo y buen sentido y un poco de naturalidad" (firmado por Soriano).

Según el experto en Florián Rey Agustín Sánchez Vidal la película "es una muestra muy a ras de suelo del 'otro' Florián, el de las comedias urbanas, sepultado por el de los dramas rurales y las comedias folklóricas". Este autor añade lo siguiente:

\footnotetext{
${ }^{48}$ Según el expediente de rodaje de la película, posteriormente se produjo un cambio en la producción.

${ }^{49}$ Archivo General de la Administración, expediente de censura de la película La Luna vale un millón, caja $36 / 0324$.

${ }^{50}$ Archivo General de la Administración, expediente de rodaje de la película La Luna vale un millón, caja 36/04674, inspección realizada el 5 de marzo de 1945.
} 
"Con todo, la mayor limitación es su previsible desarrollo y lo endeble y tópico de su cañamazo a medida que avanza el filme, con ese remate de Teresa que, al tener que elegir entre los dos sosías se decide por el banquero, y al reprocharle el vagabundo su actitud interesada ('Te quedas por él porque es el más rico') le contesta: 'No. Me quedo con él porque es el más pobre: no tiene sol, ni aire, ni nubes, ni horizontes. Hasta anoche no había visto la luna"' ${ }^{51}$. Otro autor, el periodista cinematográfico Barreira, valora así la película: "De cierta inspiración, 'a lo' René Clair en su argumento" 52.

La Comisión Nacional de Censura cinematográfica, presidida por don Antonio Fraguas ${ }^{53}$, no tuvo mayores problemas para conceder la aprobación íntegra clasificándola como tolerada para menores de 16 años. Se hicieron 13 copias de la cinta.

Una vez finalizado el rodaje, se produjeron algunos problemas burocráticos derivados del cambio de título de la película. Esta gestión no había sido tramitada correctamente y ello motivó algún intercambio de correspondencia, no siempre amable, con la administración cinematográfica.

En los documentos que hemos examinado, aparece la retribución de los principales responsables del proyecto: tanto Florián Rey como Miguel Ligero se embolsarían la nada despreciable cifra de 200.000 pesetas de la época, si bien en otros documentos las cantidades que figuran son 150.000 y 175.000 pesetas respectivamente. El presupuesto de la película se detalla con una precisión asombrosa y se elevaba a 2.223 .823 pesetas. Sin duda, este presupuesto sufrió algún aumento derivado del episodio que acabamos de relatar.

La película que nos ocupa fue estrenada en Madrid en el cine Avenida el 12 de noviembre de 1945 , con críticas desiguales ${ }^{54}$.

\footnotetext{
${ }^{51}$ Agustín SÁNCHEZ VIDAL, El cine de Florián Rey, Caja de Ahorros de La Inmaculada, Zaragoza, 1991, pág. 301.

52 Domingo BARREIRA, Biografía. Florián Rey, Agrupación Sindical de directores-Realizadores Españoles de Cinematografía, Madrid, 1968, pág. 34.

${ }^{53}$ Se trata del padre del conocido dibujante Antonio Fraguas, Forges.

${ }^{54}$ Fernando MÉNDEZ-LEITE, Historia del cine español. Tomos I y II, Op. Cit.
} 


\section{Conclusión: un episodio desconocido que ilustra el carácter sistemático de la maquinaria policial-represiva del franquismo}

Cuando los autores de este trabajo encontramos inicialmente la documentación anterior nos quedamos francamente sorprendidos ante la existencia de un episodio como el que se narra aquí. La única mención -muy vaga y sin aportar ninguna información- es la ya comentada de Manuel Rotellar y no hemos encontrado más referencias al mismo ${ }^{55}$. Ciertamente, este episodio podría haber dado lugar por sí mismo a una película. El hecho de que unas personas tan conocidas y bien conectadas socialmente como Florián Rey y Miguel Ligero pudiesen pasar varias semanas en la cárcel por una simple acusación de un único denunciante ya era llamativo. Está claro que en la época de estos acontecimientos, la justicia militar franquista tenía un papel dominante y de supremacía sobre otras instituciones del Régimen ${ }^{56}$.

De nada sirvieron los antecedentes favorables de los principales encausados en este proceso para evitar la detención inicial. El rodaje de la película quedó paralizado durante varias semanas, a pesar de los intentos que se llevaron a cabo a nivel oficial para permitir, al menos, que se permitiese la presencia del director y del protagonista en los estudios. Ciertamente, la imagen de un rodaje con la Guardia Civil custodiando al director y al protagonista habría sido digna seguramente del cine de Berlanga o Buñuel.

No cabe duda de que estos hechos serían bien conocidos por la elite cultural y artística del momento. Una detención por orden de un juzgado militar no era cosa de ser tomada a la ligera. Ciertamente, uno de los deponentes en las diligencias, Luis Muñoz Lorente (escritor y periodista) había dicho que el caso era conocido a nivel de

\footnotetext{
${ }^{55}$ Manuel ROTELLAR, "Vigencia de Florián Rey", Andalán, 272 (1980) 6 al 12 de junio, 16.

${ }^{56}$ Es posible que Florián Rey no quisiese divulgar este episodio, en parte, para no llamar la atención sobre la situación de su hermano Rafael Martínez del Castillo, que ocupó algún cargo en el bando republicano durante la Guerra Civil. En el Centro Documental de la Memoria Histórica se guarda una ficha sobre Rafael según la cual se le suponía "comunista y fue nombrado Delegado del Consejo Nacional de la Música en la Junta de Espectáculos del Gobierno Marxista" Centro Documental de la Memoria Histórica, ficha de Rafael Martínez del Castillo, expediente número 35483.
} 
calle. Es sorprendente que la detención de unas personas tan famosas no haya tenido más repercusión. Sin embargo, lo cierto es que no hemos encontrado más testimonios o memorias o referencias en la prensa acerca de este episodio.

Dos de los encausados, Rogelio Periquet Rufilanchas y Sara Giralt Gómez sumaron una estancia más en prisión. Ambos habían sido perseguidos por la República durante la Guerra Civil y ahora eran perseguidos por la justicia del bando vencedor.

Todo el procedimiento se sustenta en unas acusaciones basadas en un único denunciante y cuya gravedad, se mire como se mire, no podría pasar de lo anecdótico. Sin embargo, los mecanismos de la justicia militar, una vez puestos en movimiento, no podían detenerse tan fácilmente. El hecho de que nada menos que un ministro de Franco aparezca citado en las diligencias hacía que las averiguaciones no pudiesen paralizarse así como así. La maquinaria judicial militar franquista era sistemática y las ruedas, una vez que habían comenzado a girar, continuaban en movimiento con su trasiego de gestiones, testimonios, providencias y declaraciones.

¿Cuáles eran las motivaciones de Luis Infiesta Rojas para llevar adelante todo aquello? ¿Por qué un antiguo actor que había trabajado a las órdenes de Florián Rey se volvía ahora en su contra? Es posible que el episodio de las supuestas frases despectivas contra el ejército español existiese realmente y que Luis Infiesta actuase movido sólo por lo que él consideraba que era su deber de buen falangista. Ahora bien, mientras no aparezcan otros testimonios o documentos, siempre nos quedará la duda de que existiesen otras motivaciones más espurias. Tal vez persistiera algún antiguo resentimiento contra Florián Rey o Miguel Ligero o tal vez tratase de colaborar a toda costa con los vencedores para minimizar su propio papel como antiguo colaborador en la propaganda republicana en Aranjuez durante la Guerra Civil. En su declaración del día 3 de mayo ante el juez instructor militar, Florián Rey aludió a algún tipo de "animosidad" por parte de su denunciante.

No hay que descartar otro tipo de motivaciones menos personales. Por ejemplo, no es casual que todo el episodio se desarrolle en los días postreros de la Segunda Guerra Mundial en Europa, donde ya era prácticamente imposible la victoria de Alemania. En esta tesitura, no cabe descartar un cierto nivel de miedo e incluso pánico 
ante el futuro entre los defensores más acérrimos del régimen franquista. Tal vez la conducta del denunciante estuvo movida por una reacción orientada a fortalecer su propia posición en el entramado de fuerzas que sostenían al régimen (Falange, Guardia Civil, etc).

Por otra parte, hay indicios que podrían sugerir algún tipo de desapego de Florián Rey con el Régimen. Así, según el crítico Manuel Rotellar "está por estudiar la actitud rebelde de Florián Rey ante muchas decisiones oficiales. Actitud apasionada que le acarreó muchas reprimendas y su caída en desgracia, pues el director aragonés no contó para sus películas con una libertad absoluta, tampoco alcanzó los grandes presupuestos que se concedían a manos llenas a otros realizadores más conformistas o silenciosos. Sus dos grandes obsesiones fueron el doblaje y la protección oficial. Decía, y razón no le faltaba, que suprimiendo el doblaje el cine español se autofinanciaría sin necesidad de proteccionismos" ${ }^{27}$.

Es este un episodio lleno de coincidencias, desde la antigua relación entre Florián Rey e Infiesta, hasta la curiosa casualidad de que el agente de policía que conduce a los detenidos sea quien declara a favor de dos de los implicados, pasando por el hecho de que un ministro de Franco pasase por Aranjuez justamente en aquellos momentos e impidiese que fuesen todos apaleados y arrojados al río.

Finalmente, cuando quedó claro que las acusaciones tenían como único sustento el testimonio de Luis Infiesta Rojas, incluso avalado por el consejo del Ministro de Obras Públicas de poner todo en conocimiento de la Guardia Civil, el instructor militar no tuvo más remedio que aconsejar que se diese carpetazo al asunto. Los papeles fueron archivados y olvidados hasta que fueron puestos a disposición de la comunidad investigadora en el Archivo General Histórico de Defensa.

\section{EPÍLOGO: DESPUÉS DEL ACCIDENTADO RODAJE DE LA LUNA VALE UN MILLÓN (FLORIÁN REY, 1945)}

Al igual que sucede en muchas películas basadas en hechos reales, tiene interés seguir las peripecias de los principales protagonistas después del sorprendente

\footnotetext{
${ }^{57}$ Manuel ROTELLAR, "Vigencia de Florián Rey", Andalán, 272 (1980) 6 al 12 de junio, 16.
} 
episodio que hemos narrado. Hemos indagado en diversas fuentes documentales y no hemos encontrado datos sobre la vida de Evaristo González Aguilar y Monique Beltrán Broussoux después del episodio que acabamos de narrar.

El capitán de la Guardia Civil de Aranjuez, Luis Castro Samaniego, fue nombrado cajero suplente de la comandancia de la Guardia Civil de Madrid en noviembre de 1945 . Terminó ese año manteniendo el mando de la $2^{\mathrm{a}}$ Compañía de la Comandancia de Madrid. En enero de 1946 se le ordenó que cambiase su residencia a San Martín de Valdeiglesias, pero siguió con el mando de la $2^{a}$ Compañía de la Guardia Civil. En su hoja de servicios aparecen varias felicitaciones por diversos servicios prestados, entre ellos algunos contra "bandoleros". El antiguo "Teniente Polvorilla" alcanzó el grado de comandante y pasó a la situación de retirado en $1956^{58}$. Falleció en Madrid en noviembre de 1971. Era caballero de la Real y Militar Orden de San Hermenegildo ${ }^{59}$.

El instructor militar Alejandro Nieto Gómez siguió actuando durante 1945 en el mismo juzgado militar número 29 donde siguió las diligencias previas que hemos estudiado. En 1946 se hizo cargo del juzgado especial de delitos de atracos sin cesar en su anterior destino. En 1948 fue juez permanente de causas de la Capitanía General de la Primera Región Militar. Actuó en Madrid y localidades vecinas. En 1949 pasó a la situación de retiro al haber cumplido la edad reglamentaria ${ }^{60}$.

Luis Infiesta Rojas siguió explotando la sala de cine de Aranjuez. También gestionó cines de verano en Aranjuez, incluido el que se montaba en la plaza de toros de la localidad ${ }^{61}$. Además, siguió explotando el Gran Teatro durante bastantes años. En sus escenarios actuaron diversas compañías y artistas nacionales e internacionales. Incluso se llegó a plantear un contrato para traer en 1949 a Fred Astaire y Carmen Miranda. No cabe duda de que desde esa empresa el antiguo actor desarrolló una interesante labor cultural en Aranjuez ${ }^{62}$

\footnotetext{
${ }^{58}$ Archivo Histórico de la Guardia Civil, hoja de servicios de Luis Castro Samaniego.

${ }^{59}$ ABC-Madrid, 23 de noviembre de 1972, página 117.

${ }^{60}$ Archivo General Militar de Segovia, hoja de servicios de Alejandro Nieto Gómez.

${ }^{61}$ Francisco NOVALES "El espectáculo continúa", Op. Cit.; José Luis LINDO, "Los cines de verano en Aranjuez". Enclave, número 19, enero de 2912; 15.

${ }^{62}$ Vicente DUARTE SALGADO, Gran Teatro de Aranjuez... Op. Cit.
} 
El actor Miguel Ligero falleció en 1968. Después de su tropiezo con la justicia militar franquista, siguió rodando películas "si bien por algún tiempo estuvo en suspenso y nunca más volvería a tener oportunidad de trabajar en películas importantes" ${ }^{63}$. Su hijo, Miguel Ligero Pozas le dirigió en diversas películas.

Florián Rey había entrado en los años cuarenta en franca decadencia profesional. En una entrevista que aparece en una biografía suya, el propio Florián cita entre sus obras La luna vale un millón y añade significativamente "y después, nada; ya sabes" ${ }^{64}$. Tras La luna vale un millón, en 1948 nuestro director coincidió de nuevo con Imperio Argentina y Miguel Ligero en el rodaje de La Cigarra (Florián Rey, 1948), película que no tuvo muy buena acogida. El declive como director de éxito se puede explicar, en primer lugar, por su separación de Imperio Argentina y, por otra parte, porque tal vez no supo adaptarse al nuevo contexto cinematográfico español tras acabar la guerra. Tampoco hay que olvidar la agobiante presencia de la censura. Fue el único director de cine mudo que sobrevivió hasta la década de los cuarenta, si bien fue perdiendo el favor de la crítica y no tuvo el apoyo oficial del Régimen ${ }^{65}$. Finalmente, Florián Rey falleció en 1962.

Rogelio Periquet siguió con María Teresa Giralt ${ }^{66}$. En 1946 Florián Rey dirigirá la película Audiencia pública (Florián Rey, 1946), basada en un guión original del propio Rogelio Periquet ${ }^{67}$. No puede decirse que esta película figure entre las más celebradas del director aragonés. Periquet falleció en octubre de $1964^{68}$.

\footnotetext{
${ }^{63}$ Manuel ROTELLAR, "Vigencia de Florián Rey", Andalán, 272 (1980) 6 al 12 de junio, 16.

${ }^{64}$ Domingo BARREIRA, Biografía. Florián Rey, Agrupación Sindical de directores-Realizadores Españoles de Cinematografía, Madrid, 1968, pág. 34.

${ }^{65}$ Marta GARCÍA CARRIÓN, Sin cinematografía no hay nación. Drama e identidad nacional española en la obra de Florián Rey, Institución Fernando el Católico, CSIC, Zaragoza, 2007.

${ }^{66}$ Por ejemplo, una crónica social en $A B C$ los sitúa en un evento familiar en 1952 (ABC-Madrid, 25 de enero de 1952, página 14).

${ }^{67}$ Fernando MÉNDEZ-LEITE, Historia del cine español. Tomos I y II, Op. Cit.

${ }^{68}$ ABC-Madrid, 29 de octubre de 1964, página 64.
} 


\section{Agradecimientos}

Queremos expresar nuestro agradecimiento a las siguientes personas e instituciones que han aportado información o nos han orientado o ayudado a conseguir documentación sobre este trabajo: Biblioteca de la Universidad de Alcalá, Sociedad de Condueños de la Universidad de Alcalá, Archivo General Histórico de Defensa, Archivo Histórico de la Guardia Civil, Archivo Histórico del Ministerio del Interior, Archivo del Partido Comunista de España, Filmoteca Española, Filmoteca de Catalunya, Biblioteca de la Fundación Juan March, Archivo General de la Administración, Archivo General Militar de Segovia, Archivo General Militar de Guadalajara, Centro Documental de la Memoria Histórica, Archivo Municipal de Aranjuez, Sociedad General de Autores de España, Biblioteca Pública de Alcalá de Henares "Cardenal Cisneros”, Grupo Público de Facebook de fotografías antiguas de Aranjuez, Raúl Miranda López (Cineteca Nacional de Méjico), Nahúm Calleros Carriles (Filmoteca de la Universidad Nacional Autónoma de México) Antonia Rojas Ávila (Filmoteca de la Universidad Nacional Autónoma de México) y Arcángel Bedmar, Angel Pueblas (Gabinete de Fotografía Científica de la Universidad de Alcalá) así como a los evaluadores de este manuscrito que han aportado nuevas ideas en la redacción final. 